DOI 10.22363/2312-9220-2021-26-2-317-320

УДК $82.09(47=512.145)$

Рецензия / Book review

\title{
Мифологический мир
}

в художественных текстах тюркоязычных народов: рецензия на книгу: Шаряфетдинов P.X. «Мифопоэтика татарской литературы»: монография. М. - Берлин: Директ-Медиа, 2021. 168 с.

\author{
И.А. Таирова \\ Российский новый университет, \\ Российская Федеращия, 105005, Москва, ул. Радио, д. 22 \\ $\square$ irma-irma@list.ru
}

\begin{abstract}
Аннотация. Рассматриваются новые разработки в области мифопоэтики, основанные на татарском художественном материале. Анализируется мифо-религиозный подход исследователя, позволяющий на глубинном уровне изучить влияние культурных, философских и религиозных реалий на татарскую литературу. С этой целью разбираются татарские космогонические представления, мифологизм растительного и животного миров в произведениях Кул Гали, Мухаммедьяра, Г. Кандалыя, Дэрдменда, Г. Тукая, Ф. Бурнаша, Н. Исанбета, М. Джалиля, Ф. Карима, М. Хабибуллина, Н. Фаттаха, Р. Кутуя, Р. Файзуллина, Р. Зайдуллы, Г. Яхиной.
\end{abstract}

Ключевые слова: миф, татарская литература, мифопоэтика, Тенгри, суфийская символика

Заявление о конфликте интересов. Автор заявляет об отсутствии конфликта интересов.

История статьи: поступила в редакцию 10 января 2021 г.; принята к публикации 25 января 2021 г.

Для цитирования: Таирова И.А. Мифологический мир в художественных текстах тюркоязычных народов: рецензия на книгу: Шаряфетдинов Р.Х. «Мифопоэтика татарской литературы»: монография. М. - Берлин: Директ-Медиа, 2021. 168 с. // Вестник Российского университета дружбы народов. Серия: Литературоведение. Журналистика. 2021. T. 26. № 2. C. 317-320. http://dx.doi.org/10.22363/2312-9220-2021-26-2-317-320

(C) Таирова И.А., 2021

(c) () This work is licensed under a Creative Commons Attribution 4.0 International License https://creativecommons.org/licenses/by/4.0/ 


\title{
The Mythological World \\ in the Literary Texts of the Turkic-speaking Peoples: Book review of: Sharyafetdinov, R.Kh. (2021). Mythopoetics of Tatar literature: Monograph. Moscow, Berlin, Direct-Media
}

\author{
Irina A. Tairova \\ Russian New University, \\ 22 Radio St, Moscow, 105005, Russian Federation \\ $\checkmark$ irma-irma@list.ru
}

\begin{abstract}
The review of the monograph by R.Kh. Sharyafetdinov "Mythopoetics of Tatar Literature" deals with new developments in the field of mythopoetics, based on Tatar artistic material. The mytho-religious approach of the researcher is analyzed, which makes it possible to study at a deep level the influence of cultural, philosophical, and religious realities on Tatar literature. For this purpose, the author of the scientific work examines the Tatar cosmogonic ideas, the mythologism of the plant and animal worlds in the works of Kul Gali, Mukhammedyar, G. Kandaly; Dardmend, G. Tukay, F. Burnash, N. Isanbet; M. Jalil; F. Karim; M. Khabibullina, N. Fattakh, R. Kutuy, R. Faizullin; R. Zaydulla, G. Yakhina.
\end{abstract}

Keywords: myth, Tatar literature, mythopoetics, Tengri, Umai, Sufi symbols

Conflicts of interest. The author declares that there is no conflict of interest.

Article history: submitted January 10, 2021; revised January 15, 2021; accepted January $25,2021$.

For citation: Tairova, I.A. (2021). The mythological world in the literary texts of the Turkic-speaking peoples: Book review of: Sharyafetdinov, R.Kh. (2021). Mythopoetics of Tatar literature: Monograph. Moscow, Berlin, Direct-Media. RUDN Journal of Studies in Literature and Journalism, 26(2), 317-320. (In Russ.) http://dx.doi.org/10.22363/23129220-2021-26-2-317-320

Миф издревле являлся почвой для создания литературных мотивов и образов. Культура каждого народа хранит память о своем историческом прошлом, опирающемся на древние представления и поверья. Мифологическое сознание находит свое отражение сначала в устном народном творчестве, фольклоре, затем в национальной литературе. В этом отношении татарская литература не является исключением. Начиная с V-VI вв., тюркотатарская традиционная духовная культура обнаруживает себя в различных письменных источниках: рунических надписях; Орхоно-Енисейских памятниках, датированных VII-XI вв. и др. Далее древнетюркское мировоззрение продолжает жить в татарской мифопоэтике, интерпретирующей мифологические характеры своих предков (Г. Тукай, Г. Исхаки и др.). К мифу как способу мироощущения и как стилистическому приему прибегают и современные татарские авторы, создающие представление о поэтической картине мира своего народа (Р. Зайдулла, Г. Яхина и др.). Поэтому проблема изуче- 
ния национальной картины мира, неразрывно связанной как с природой мифа, так и взаимодействием его с литературой, стала предметом изучения таких авторов, как В.А. Фащенко, Л.И. Шевченко, Ч.Г. Гусейнов, А. Арутюнов, К.К. Султанова.

Эту тему, но теперь уже в свете татарской литературы, продолжил исследователь Московского педагогического государственного университета Р.Х. Шаряфетдинов. Он акцентирует внимание на том, что «авторы национальных литератур, создавая свои собственные или чаще всего актуализируя уже существующие национальные мифы, легенды, притчи, сказания и т. п., таким образом реконструировали архаические структуры сознания, нередко стремились свести всю событийную пестроту человеческого бытия к немногим мировоззренческим, нравственно-эстетическим знаменателям, чтобы в лаконичной форме запечатлеть коллективный опыт человечества, дать универсальную модель мира».

Монография Р.Х. Шаряфетдинова имеет четкую структуру, состоит из Введения, четырех глав и заключения.

Во введении исследователь говорит об актуальности изучения традиционной культуры тюркского народа и важности отражения его народной духовной культуры в литературе. Приводя различные определения мифа, ученый убеждается, что наиболее действенным для исследования ему видится мифо-религиозный подход, позволяющий углубиться в «культурную память и традиции» татарского народа с целью «определить культурные, философские, религиозные явления, оказавшие наибольшее влияние на творческое сознание авторов».

Первая глава монографии посвящена научным исследованиям проблемы взаимодействия мифа и литературы. Автор рассказывает о заслугах зарубежных и отечественных научных школ, начиная с XIX века, раскрывая специфику концепций их представителей. Отдельный параграф он отводит рассмотрению научных подходов к изучению мифопоэтики национальной литературы. Здесь же на примере произведений русскоязычных писателей и писателейбилингвов, выходцев из народов, бывших в составе СССР, СНГ, а затем РФ, исследователь рассматривает национальные мифопоэтические модели на примере конкретных произведений (Ю. Рытхэу «Когда киты уходят»; Ч. Айтматова «Белый пароход», «Пегий пес, бегущий краем моря» и др.).

Во второй главе речь идет о мифологических представлениях татарского народа. Такие космогонические образы, как небо, солнце, луна, звезды, а также соответствующие им божества (Тенгри, Умай и др.), мотив ветра, представление о пространстве легли в основу литературных сочинений татарского народа и произведений отдельных авторов. Образы астральных мифов рассматриваются на примерах текстов Кол Гали; Ю. Баласагуни; М.М. Хабибуллина, Р. Зайдуллы и др.). Подробно исследуется мотив Земли, культ деревана материале сочинений классической (Ф. Карими; Ф. Бурнаш; Н. Исанбет и др.) и современной (Р. Файзуллин и др.) татарской литературы.

Интересную параллель автор монографии проводит с мифами о животных и отражением этих образов в татарской литературе. Достаточно подробно эта тема исследуется на примере творчества Г. Яхиной. Раскрывают- 
ся значения образов зверей, птиц, насекомых: медведя, оленя, волков, белки, зайца, рябчика, тетерева, глухарей, ласточек, стрекоз, пчел, шмелей и др.

В третьей главе представлен материал о мифологических образах человека (мужчины, женщины, матери; ребенка). Отдельно рассматриваются образы мифологизированных лиц (повитухи; колдуна; мудреца; Мудрого Старца; Учителя), а также исторических личностей и религиозных деятелей.

Отдельное внимание уделяется «концепции сверхчеловека в ее личностном, социально-историческом, общечеловеческом аспектах». Немаловажное значение отводится суфийской тематике. Исследователь отмечает, что «само течение [суфизм] - знаковое место как в религиозной, так и в культурной жизни татар», оттого «суфийские символы, формирующие смысловую двуплановость, обнаруживаются в целом пласте произведений татарской поэзии начала XX века».

Четвертая глава посвящена «Отображению религиозных воззрений татарского народа в литературе». Рассматриваются такие мифологемы языческих воззрений, как мифические силы: боги (Йер-Су, Гуар, Эрклиг и др.), духи (Ляу-сазаган, Толпар, Хумай), мифические чудовища (Дракон Аждаха, Шурале), демоны, джинны и т. п. После принятия татарами ислама (Х в.) в литературу входят образы нового религиозного ряда: Бога-Творца (Аллах); ангелов (Ангел смерти); пророков, святых (Сулейман, Дауд, Хозыр-Ильяс). Также, автор отмечает, появляются образы, связанные с религиозными обрядами (Молитва, пост в месяц Рамадан), ритуальными предметами (Коран).

Выводы, которые делает автор монографии, в первую очередь, касаются татарской мифологической школы, которая (автор соглашается с Д.Ф. Загидуллиной) до сих пор не сформировалась. В этой связи разработки рассматриваемой монографии представляются весьма важными. Тем более что татарские классики и современные авторы (пишущие на русском и татарском языках) часто прибегают к использованию мифологизированных образов в своих произведениях.

Резюмируя вышесказанное, отметим, мифологемы художественных текстов заключают в себе коллективное бессознательное, народную память. Подсознательная тяга к пракорням, закодированным в мифологических образах, позволяет размышлять о духовных и нравственных устоях, формирующих национальную идентичность, в данном случае - тюркоязычных народов.

\section{Сведения об авторе:}

Таирова Ирина Александровна, кандидат филологических наук, доцент, кафедра русского языка и издательского дела, Российский новый университет.

\section{Bio note:}

Irina A. Tairova, $\mathrm{PhD}$ in Philology, Associate Professor, Department of Russian Language and Publishing, Russian New University. 